\author{
M.Sh. Shapay ${ }^{1}$, A.E. Ibraeva², S.A. Mukash ${ }^{3}$ \\ ${ }^{1}$ 2nd-year master's student, L. N. Gumilyov Eurasian National University, Kazakhstan, Nur- \\ Sultan, \\ e-mail: madilennne@gmail.com \\ ${ }^{2}$ associate Professor of regional studies, e-mail: aigerimibrayeva7@gmail.com \\ ${ }^{3}$ Lecturer, e-mail: saltanat@inbox.ru
}

\title{
MIGRATIONAL FLOW FROM CENTRAL ASIA TO THE EUROPEAN UNION
}

\begin{abstract}
The system of international relations is constantly changing, where there are new challenges, problems, certain trends. In this sense, global migration is no exception. In this paper, we are talking about the fact that migrants from Central Asia in recent years are directed against the traditional vector, where Russia is replaced by other European countries.

Such a trend cannot be short-term for a number of internal and external reasons, where globalization, leveling the natural borders of States, contributes to the gradual growth of world migration. Moreover, the leading European countries with a high level of economic development have always attracted foreigners who were in search of work and a better life. Other reasons for the urgency of this problem include the rapid demographic development of Central Asia, the interest of European countries in cheaper labor, but, nevertheless, sufficiently qualified. In addition, the economic crisis in Russia, the complication of migration policy, the weakening of the currency exchange rate, as well as the dependence of the budget of the Central Asian countries on remittances from abroad in the complex provoke a great interest in changing the traditional migration direction.

The aim of the work is to investigate the phenomenon of gradual increase in the number of migrants from Central Asia to Europe and to analyze the causes and consequences of this phenomenon in the context of the current international situation.

Based on the results of the review of the problem, it is concluded that the number of migrants from Central Asia in the European Union is gradually increasing. In the next decades, this phenomenon will also be relevant due to the high birth rate and relatively young average age of citizens in Central Asia, the EU's need for cheap and at the same time skilled labor, the low level of the Central Asian economy and the economic crisis in Russia.
\end{abstract}

Keywords: Central Asia, European Union, migration, economic crisis.

М.Ш. Шапай ${ }^{1}$, А.Е. Ибраева², С.Ә. Мұқаш ${ }^{3}$

12-курс магистранты, Л.Н.Гумилев атындағы Еуразия ұлттық университеті, e-mail: madilennne@gmail.com, Қазақстан, Нұр-Сұлтан қ.

2аймақтану кафедрасының доценті, e-mail:aigerimibrayeva7@gmail.com

3 аға оқытушы, e-mail: saltanat@inbox.ru

\section{ОРТАЛЫК АЗИЯДАН ЕУРОПАЛЫК ОДАҚ ЕЛДЕРІНЕ МИГРАЦИЯ АҒЫНЫ}

Андатпа

Халықаралық қатынастар жүйесі тұрақты өзгеруде, онда жаңа сын-қатерлер, проблемалар, белгілі бір трендтер пайда болуды. Бұл мағынада жаһандық миграцияға да бұл аталғандар қатысты. Бұл мақалада соңғы жылдары Орталық Азиядан көшіп-қонушылардың Ресейдің 
орнына Еуропаның басқа елдері келген, дәстүрлі қалыптасқан бағытқа қарсы ұмтылуы туралы айтылады.

Мұндай үрдіс мемлекеттердің табиғи шекараларын төмендететін жаһандану әлемдік көшіқонның біртіндеп өсуіне ықпал ететін бірқатар ішкі және сыртқы себептерге байланысты қысқа мерзімді болып табылмайды. Сонымен қатар, экономикалық даму деңгейі жоғары Еуропаның жетекші елдері жақсы жұ-мыс және жақсы өмір жағдайларын іздеуде жүрген шетелдіктерді әрдайым қызықтырды. Бұл проблема-ның өзектілігінің басқа себептерінің ішінде ОА-ның жедел демографиялық дамуын, еуропалық елдердің неғұрлым арзан, бірақ, соған қарамастан, жеткілікті білікті жұмыс күшіне қызығушылығын айтуға бола-ды. Бұдан басқа, Ресейдегі экономикалық дағдарыс, көші-қон саясатының күрделенуі, валюта бағамының әлсіреуі, сондай-ақ ОА елдері бюджетінің шетелден ақша аударымдарына тәуелділігі кешенді түрде дәс-түрлі миграция бағытын ауыстыруға үлкен қызығушылық тудырады.

Жұмыстың мақсаты-Орталық Азия елдерінен Еуропаға көшіп-қонушылар санының біртіндеп көбеюінің феноменін зерттеу және өзекті халықаралық ахуалдың контекстінде осы құбылыстың себептері мен салдарын талдау.

Мәселені қарау қорытындысы бойынша Еуропалық Одақ елдеріндегі Орталық Азиядан көшіп-қону-шылардың саны бірте-бірте ұлғайып келе жатқаны туралы қорытынды жасалады. Келесі онжылдықта бұл феномен ОА елдеріндегі бала туудың жоғары қарқынына және азаматтардың орта жас жасына қатысты, ЕО-ның арзан және бір мезгілде білікті жұмыс күшіне деген қажеттігіне, OA экономикасылық әлеуетіне және Ресейдегі экономикалық дағдарысқа байланысты өзекті болады.

Түйін сөздер: Орталық Азия, Еуропалық Одақ, көші-қон, экономикалық дағдарыс.

Шапай М.Ш. ${ }^{1}$, Ибраева А.Е. ${ }^{2}$, Мукаш С.А. ${ }^{3}$

${ }^{1}$ магистрант 2-курса, Евразийский национальный университет имени Л.Н. Гумилева, Казахстан,

г. Нур-Султан, е-mail: madilennne@ gmail.com

${ }^{2}$ доцент кафедры регионоведения, e-mail: aigerimibrayeva7@gmail.com

${ }^{3}$ старший преподаватель, e-mail: saltanat@inbox.ru

\section{МИГРАЦИОННЫЙ ПОТОК ИЗ ЦЕНТРАЛЬНОЙ АЗИИ В ЕВРОПЕЙСКИЙ СОЮЗ}

Аннотация

Система международных отношений постоянно меняется, появляются новые вызовы, проблемы, определенные тенденции. В этом смысле глобальная миграция не является исключением. В данной статье речь идет о том, что мигранты из Центральной Азии в последние годы направляются против традицион-ного вектора, где Россия вытесняется другими европейскими странами.

Такая тенденция не может быть краткосрочной по ряду внутренних и внешних причин, где глобализация, выравнивая естественные границы государств, способствует постепенному росту мировой миграции. Более того, ведущие европейские страны с высоким уровнем экономического развития всегда привлекали иностранцев, находившихся в поисках работы и лучшей жизни. К другим причинам актуаль-ности этой проблемы можно отнести стремительное демографическое развитие Центральной Азии, заинтересованность европейских стран в более дешевой рабочей силе, но, тем не менее, достаточно квалифицированной. Кроме того, экономический кризис в России, усложнение миграционной политики, ослабление валютного курса, а также зависимость бюджета стран Центральной Азии от денежных переводов из-за рубежа в комплексе провоцируют большой интерес к изменению традиционного направления миграции.

По результатам рассмотрения проблемы сделан вывод о том, что количество мигрантов из Централь-ной Азии в Евросоюзе постепенно увеличивается. В ближайшие десятилетия 
этот феномен также будет актуален в связи с высокой рождаемостью и относительно молодым средним возрастом граждан в Центральной Азии, потребностью ЕС в дешевой и в то же время квалифицированной рабочей силе, низким уровнем развития экономики Центральной Азии и экономическим кризисом в России.

Ключевые слова: Центральная Азия, Европейский Союз, миграция, экономический кризис.

Introduction. Migration flows from the Central Asian region to European countries are still a poorly understood problem, despite its scale. In accordance with the data UN the number of migrants from Kazakhstan to the countries of Northern, southern, Western Europe from 2010 to 2015 was increased from 1040 to 1377082940 people per year [1].

Migration plays a vital role in the socio-economic history of Europe and Central Asia. It is believed that policy changes should not be based on possible isolation from each other. Policy reforms should help migrants cope with increased and unavoidable flexibility in labour markets. The number of migrants from Central Asia to Russia is still large, but the focus of this work is focused on the migration movement from Central Asian countries to the EU. Due to the fact that the migration issue is important in the policy of the Central Asian countries, various documents, agreements and statements of top officials regarding this sphere were also considered.

Over the years, European countries have gradually developed their migration policy, at times tightening it, and at times, on the contrary, contributed to the growth of immigration. The current situation is complicated by the crisis, which is associated with an unprecedented flow of refugees since 2014 from Africa and the Middle East to Europe.

\section{INTERNAL AND EXTERNAL REASONS FOR THE GROWTH OF MIGRATION FROM CENTRAL ASIA TO EUROPE}

Various works of researchers usually emphasize the established point of view about traditional migration routes from Central Asia to the Russian Federation due to at least a common Soviet past.

One of the main reasons for the increase in labor exports is the growth of the population of Central Asia. 2016 in five countries lived a little more than 69 million people [2]. The total population growth in 2016 compared to 2000 amounted to more than 14 million. The National Institute For Strategic Studies of the Kyrgyz Republic has predicted the growth of the population of Central Asia by 2050 [3].

Thus, according to the forecast, the growth will be about 27 million people. It is interesting to compare this forecast with another concerning the population of the European Union by 2050. The official website of the European statistics presents data that more than 528 billion people will live in the EU by the middle of the XXI century. Comparing both forecasts, it turns out that the population growth rates in the five Central Asian countries will significantly exceed the growth rates in the European countries [4].

The next reason is the average age of the population. In Central Asia, the figure is 26 years [5]. In Europe, the average has been around for almost 40 years. As for the able-bodied citizens of Central Asia (15-64 years), there are $65-67 \%$ of the total population. On the one hand, this may have a positive impact on the economies of Central Asia, on the other hand, the growth of the urban working-age population creates an additional burden on the labor market, which may result in another incentive for labor migration. If the domestic market does not provide sufficient and attractive conditions for employment, citizens are sent to study in other countries [6].

Remittances of CA citizens home represent significant amounts. In 2013, Tajikistan received 4.1 billion US, which amounted to more than $40 \%$ of the country's GDP [7]. Tajikistan is considered one of the poorest countries in the region, whose budget is directly dependent on remittances or the number of migrant workers outside their country. In the same year, more than 2 billion was sent to the Kyrgyz Republic. US, which was $31 \%$ of GDP. The leader among the Central Asian countries in remittances in the same year was Uzbekistan (about 6.7 million). Kazakhstan and 
Turkmenistan received 561 million US and 40 billion US respectively [8]. Thus, 3 out of 5 countries, which represent $67 \%$ of the total population of Central Asia, are actually dependent on migration flows.

Labor migration has become significantly more difficult, on the one hand, the migration crisis, which has caused a tightening of immigration policy of the European Union, on the other hand, the economic crisis in the Russian Federation, politics of sanctions by Western countries against Russia and depreciation of ruble and the devaluation of income in the domestic market. According to the Central Bank of Russia, 5.065 billion was transferred to Central Asian countries in 2015 and 12.177 billion in 2014 [9]. In this sense, remittances of migrant workers have indeed decreased by $60 \%$. Consequently, States heavily dependent on foreign remittances are forced to actively seek out countries with the most stable economies and high wages [10].

Thus, summing up the intermediate result, it can be stated that international migration will continue to grow for various reasons. The number of labour migrants will increase. Among the reasons for the interest of Central Asian citizens in emigration are both internal and external. Domestic problems include: the rate of birth, the relatively young average age of the population, domestic economic problems (lack of quality infrastructure, poverty, unpreparedness of the market for a large number of workers), the dependence of a number of countries on remittances and work abroad. External causes include the migration crisis in the EU, the economic crisis in Russia and the weakening of the ruble.

Of course, there are a number of other internal and external reasons, but those that have been analyzed in this paper are of the greatest importance in the issue of increasing migration from Central Asia to Europe.

\section{CURRENT TYPES OF MIGRATION FOR CENTRAL ASIAN COUNTRIES}

The migration issue in the XXI century remains one of the most important structural elements of the system of international relations. According to the report of the UN General Assembly, from 1950 to 2015, the population of rich countries each year on average increased from 0.3 billion to 3.2 billion people due to net positive migration, which makes it possible to speak about the high level of influence of this factor on the entire world system [11].

According to the International organization for migration (IOM), in 2015 more than 760 thousand citizens of Kyrgyzstan (11.35\% of the total population) left their country. At the same time, the EU accounted for more than 94 thousand, or $12.5 \%$, of immigrants. The level of external emigration of Kazakhstan in comparison with Kyrgyzstan was higher $-18.78 \%$, of which $26.9 \%$ immigrated to Europe. Migration from Tajikistan to Europe $-5.5 \%$; Turkmenistan $-4.2 \%$; Uzbekistan $-3.26 \%$.

Germany is a leading recipient of immigrants from Central Asia. After Germany, citizens of Central Asian countries choose such highly developed countries as the United Kingdom, France, Italy, Austria; the second group of host countries include Scandinavian and Baltic countries; the third group, where few or no go - Slovenia, Serbia, Romania, Portugal.

The most popular types of migration from Central Asia to the EU include family, economic and educational, as well as migration for political reasons. In addition, the problem of family reunification has been an urgent one for the last few decades. For example, the German Diaspora in Central Asia (more than 70 thousand Germans), which lived there during the Soviet period, began to return to their homeland gradually since the 1990 s. Every year, the European population increasingly sought to return to their native countries.

Insecurity of borders, new economic difficulties, as well as the introduction of language policyall this affected, first of all, the lives of non-indigenous peoples. In addition to the repatriation of European diasporas, the indigenous peoples of Central Asia fled to Europe for various reasons: immigration during the civil war of 1918-1922, famine in the 1920s, collectivization in the 1930 s, deportation of Germans and Koreans in 1937-1941, military evacuation in the 1940s, World war II, and the collapse of the Soviet Union. 
With regard to labour migration, in 2011 The organisation for economic co-operation and development (OECD) has released a major work with a statistical study on migration from developing to developed countries. In the context of this study, three Central Asian countries were considered: Kazakhstan, Kyrgyzstan and Tajikistan.

Migrants from Kyrgyzstan mainly chose countries such as the United States, Israel, Turkey, Canada, Germany, Great Britain, Austria, Italy, France, Greece, the Czech Republic.

The level of migration of Kazakhstan to OECD countries showed an amazing picture. The main countries of stay of Kazakh emigrants: Germany, Greece, USA, Israel, Turkey, Canada, great Britain, Poland, Czech Republic, Estonia (2011). In Germany in 2011 lived more than 800 thousand immigrants from Kazakhstan, while in the United States and other countries almost 200 thousand.

In addition to labor and family, educational or educational migration should be separately noted. The number of international students of Kyrgyzstan in Germany grew every year (2008-425 students, 2010-523 students, 2017-533 students). In addition to Germany, the number of students from Kyrgyzstan grew every year in Austria and France. Students from Kazakhstan preferred to study in the UK (2008-1178 students, 2010-2054 students, 2017-2010 students), in the Czech Republic (2008-332 students, 2010-679 students, 2017-979 students), in Germany (2008 - 668 students, 2010 to 701 students in 2017 - 693 students).

The number of international students increases annually due to bilateral agreements and programs. More and more agreements on mutual cooperation between the countries of Central Asia and the European Union are being signed, for example, the new interregional strategy "European Union and Central Asia: strategy for a new partnership" in 2007. The Regional agreement covers different areas of cooperation, from political to socio-economic. Among the different programmes of this new partnership agreement is the BOMCA "border management assistance programme in Central Asia", which discusses technical and regulatory issues of border management in Central Asia [12]. New steps for cooperation between regions have opened up new opportunities for migration, but at the same time different external and internal causes can have a negative impact.

\section{THE IMPACT OF THE MIGRATION CRISIS ON EU-CA RELATIONS}

Migration as a process is really important in socio-economic history. Many people find in this salvation from political and other persecution, others see an opportunity to escape poverty. The migration crisis facing the European Union is forcing it to take more serious measures and reform its migration policy. However, the measures taken should not limit the positive impact of migration, in which the Central Asian countries are interested. Migration has for many years been considered a mechanism that can give impetus to economic growth.

Nevertheless, the migration crisis has an impact on the current format of relations between the EU and Central Asia. The number of third-country nationals illegally present in the EU rose sharply in 2015 to 2,154 million. In 2016, dropped to 983860 and continued reduction in 2017 to 618780 people. In this regard, there is an increase in public dissatisfaction with the migration policy, which is carried out in the EU [13]

The large flow of refugees has led to the fact that the issue of immigration has become one of the most important problems faced by European countries in recent times. In 2015, in a survey of European residents, 58\% of respondents noted this problem. However, already in 2017, this percentage fell to $38 \%$, and the threat of terrorism in Europe took the lead.

Changes in the EU migration policy primarily affected refugees, quota allocation and protection of their rights. An agreement was signed between the EU and Turkey in 2016 on border control and monetary support to the Turkish state from the EU. Turkey was the main transit point for Syrian refugees. According to the text of the agreement, Turkey had to close the way to refugees in the EU, which reduced the number of illegal entries into Europe. 
The EU today needs additional workers, but due to the fact that refugees are mostly low-skilled workers and many of them remain to live inside the EU, the requirements for economic migrants are increasing at times.

Without sustainable international migration and a coordinated migration policy of the European Union, the number of people of working age among the population of Europe will decrease by 20 million, so the EU must build a unified and balanced policy in relation to this problem.

Despite all the measures taken, economic migration will be carried out and quantitatively increased. The EU has every chance to cope with the consequences of the migration crisis. Europe is interested in global migration processes for many reasons, as are the countries of Central Asia, which continue to look for new places to work abroad.

Conclusion. Global migration cannot be outside the international political framework, so global, regional and local problems and challenges have an impact on the nature and extent of migration. The study found that the number of migrants from Central Asia in Europe is growing. The number of women migrating to the EU has continued to increase since the beginning of the new Millennium. It is also noted that the five countries of the Central Asian region are characterized by different types of migration: family, labor (economic), educational and migration for political reasons. The article presents tables and charts that demonstrate current migration data.

In 2014, Europe faced a migration crisis triggered by the war in Syria. In this regard, changes in the EU migration policy have an impact on labor migration from Central Asia, where conditions for entry into the territory of European countries are gradually tightening. Despite the difficulties, the number of labour migrants does not decrease for a number of other reasons.

External reasons that stimulate migration include the economic crisis in Russia and the depreciation of the ruble. Russia is a country where migrants from Central Asian countries have been sent for many years. Nevertheless, the situation is gradually changing. Russia is now under numerous Western sanctions, making it a less attractive place to earn money. Remittances of migrant workers have more than halved.

Of course, despite the new problems from the outside, there are a number of internal reasons affecting the growth of migration from Central Asia to the EU. The gradual growth of the population of Central Asia, the presence of a large number of able-bodied citizens, the dependence of the budgets of Central Asian countries on remittances, as well as internal economic problems encourage migrants to move to more attractive countries for earnings and training, which are the countries of the European Union.

References:

UN Statistics on international migration. URL: http://www.un.org/en/development /desa/population /migration/data/estimates2/data/UN_MigrantStock Total_2015.xlsx (accessed 28.12.2017).

Institute of demography, Higher school of Economics. "15 new independent States. Population at the beginning of the year, 1950-2016, thousands of people". URL: http://www.demoscope.ru/weekly/ssp/sng_pop.php (date accessed: 28.12.2017.

Cactus Media news Agency. "NISI: by 2050, the population of Central Asia will reach 96 million." URL: https://kaktus.media/doc/329511_nisi:_k_2050_gody_ chislennost_naseleniia_centralnoy_azii_dostignet_96_mln.html (date accessed: 28.12.2017).

Official website of the statistical service of the European Union. URL: http://ec.europa.eu/ eurostat/data /database (accessed 28.12.2017).

The world Factbook of the CIA. URL: https://www.cia.gov/library/publications/download/ download-2012/index.html (date accessed: 28.12.2017).

Europe - the average age of the population. "List of countries and map". http://ru.worldstat.info/ Europe/List_of_countries_by_Total_media_page (date accessed: 28.12.2017).

World bank. Brief information on migration and development. "Migration and remittances: recent trends and prospects, 2013-2016". URL: http://www.worldbank.org/ 
en/news/features/2013/10/02/migration-and-remittances-flows-in-europe-and-central-asiarecent-trendsand-outlook-2013-2016 (accessed 28.12.2017).

Information Agency "Fergana". "In 2016, the volume of remittances from Russia to Central Asia grew to $\$ 6.980$ billion." URL: http://www.fergananews.com/ news/26167 (date accessed: 28.12.2017).

The Central Bank of the Russian Federation. External sector statistics. "Cross-border transfers of individuals". URL: http://www.cbr.ru/statistics/?Prtid=svs\&ch=Par_17101\#CheckedItem (accessed 28.12.2017).

News Agency "Migrant.Fergana.ru». "Transfers of labour migrants from Russia to Central Asia collapsed by 60 percent in 2015." URL: http://migrant.ferghana.ru/newslaw / transfers-migrant workers-from-Rossi.html (date accessed: 28.12.2017)

Report of the UN Secretary-General to the 71st session. International migration and development.

http://www.un.org/en/development/desa/population/migration/generalassembly/docs/A_71_

296_R.pdf (accessed 22.11.2017)

Border management in Central Asia, EU, 2015, DIOR: http://www.rs.gov.lv/faili/doc2013 / bomca_newsletter 08 dec.pdf (date accessed: 08.02.2018)

Official website of the statistical service of the European Union. URL: http://appsso.eurostat.ec.europa.eu/nui/show.do?dataset=migr_eipre\&lang=en (accessed 16.05.2018).

Пайдаланылған әдебиеттер тізімі:

1. БҰҰ Халықаралық көші-қон статистикасы. URL: http:/www.un.org/en/development / desa / халық / көші-қон/деректер / бағалау 2 / деректер / UN_MigrantStock Total_2015.xlsx (Байланыс күні 28.12.2017).

2. Экономика жоғары мектебінің демография институты. "15 жаңа тәуелсіз мемлекет. Жыл басындағы халық саны, 1950-2016, мың адам". URL: http://www.demoscope.ru/weekly/ssp/sng_pop.php (өтініш берген күні: 28.12.2017.

3. Cactus Media ақпараттық агенттігі. "НИСИ: 2050 жылға қарай Орталық Азия халқы 96 миллион адамға жетеді." URL: https://kaktus.media/doc/329511_nisi:_k_2050_gody_ chislennost_naseleniia_centralnoy_azii_dostignet_96_mln.html (өтініш беру күні: 28.12.2017).

4. Еуропалық Одақтың статистикалық қызметінің ресми веб-сайты. URL: http://ec.europa.eu / ЕУРОСТАТ / деректер / деректер базасы (жүгінген күні 28.12.2017).

5. ЦРУ фактілерінің Дүниежүзілік анықтамалығы. URL: https://www.cia.gov/library/publications/download/ download-2012/index.html (өтініш беру күні: 28.12.2017).

6. Еуропа-халықтың орташа жасы. "Елдер тізімі және карта". http://ru.worldstat.info / Еуропа / List_of_countries_by_Total_media_page (Байланыс күні: 28.12.2017).

7. Дүниежүзілік банк. Көші-қон және даму туралы қысқаша ақпарат. "Көші-қон және ақша аударымдары: соңғы тенденциялар мен перспективалар, 2013-2016 жылдар". URL: http://www.worldbank.org/ en/news/features/2013/10/02/migration-and-remittances-flows-ineurope-and-central-asia-recent-trendsand-outlook-2013-2016 (өтініш берген күні 28.12.2017).

8. "Ферғана" ақпараттық агенттігі. "2016 жылы Ресейден Орталық Азияға ақша аударымдарының көлемі \$6,980 млрд дейін өсті" URL: http://www.fergananews.com / жаңалықтар / 26167 (хабарласу күні: 28.12.2017).

9. Ресей Федерациясының Орталық Банкі. Сыртқы сектор статистикасы. "Жеке тұлғалардың трансшекаралық аударымдары". URL: http://www.cbr.ru/statistics/?Prtid=svs\&ch=Par_17101\#CheckedItem (өтініш берген күні 28.12.2017).

10. Ақпараттық агенттік "Мигрант.Fergana.ru". " 2015 жылы Ресейден Орталық Азияға еңбек мигранттарының ағымы 60 пайызға азайды."URL: http://migrant.ferghana.ru/newslaw / мигрант аудармалары жұмысшылар-from-Rossi.html (өтініш беру күні: 28.12.2017) 
11. 71-ші сессияның БҰҰ Бас хатшысының баяндамасы. Халықаралық көші-қон және даму.

http://www.un.org/en/development/desa/population/migration/generalassembly/docs/A_71_ 296_r. pdf (жүгінген күні 22.11.2017)

12. Орталық Азиядағы Шекараларды басқару, EO, 2015, DIOR: http://www.rs.gov.lv/faili/doc2013 / bomca_newsletter 08 dec.pdf (жүгінген күні: 08.02.2018) 13. Еуропалық Одақтың статистикалық қызметінің ресми веб-сайты. URL: http://appsso.eurostat.ec.europa.eu/nui/show.do?dataset=migr_eipre\&lang=en (өтініш берген күні 16.05.2018). 